\title{
FÜRDŐTURISTÁK ELÉGEDETTSÉGÉNEK VIZSGÁLATA SERVQUAL MODELL ALAPJÁN
}

\section{EXAMINING THE SATISFACTION OF BATH TOURISTS BASED ON THE SERVQUAL MODEL}

\author{
Szabó Zoltán ${ }^{1 *}$ \\ ${ }^{1}$ Területfejlesztés és Menedzsment Csoport, Gazdaságmódszertani Tanszék, Georgikon Kar, \\ Pannon Egyetem, Magyarország \\ https://doi.org/10.47833/2020.3.ECO.001
}

\section{Kulcsszavak:}

fogyasztói magatartás

fürdőturizmus

ServQual modell

Szentesi Fürdő

\section{Keywords:}

consumers behavior

ServQual model

spa tourism

Szentes SPA

\section{Cikktörténet:}

Beérkezett 2020. szept 2.

Átdolgozva 2020. szept. 19.

Elfogadva 2020. szept. 22.

\begin{abstract}
Összefoglalás
Az egészségturizmus fontossága és az iránta megnövekedett érdeklődés ellenére nemzetközileg még kevés tanulmány foglalkozik a fürdőturizmussal. A fürdőturizmus szolgáltatásaival kapcsolatos vendég-elégedettségi kutatásokra hazai viszonylatban rendkívül kevés utalás található. A kutatás célja a tág értelemben vett vidéken élö magyar középkorú középosztály elégedettségének megismerése és feltárása a Szentesi Fürdő szolgáltatásaival kapcsolatosan, mely segítséget nyújthat a fürdö menedzsmentje számára a döntéselökészitésben.
\end{abstract}

\begin{abstract}
Importance of health tourism and the growing intereset spite of there are still few international studies on spa tourism. There are very few references to guest satisfaction research on spa tourism services in Hungary. Aim of research is to find out explore the satisfaction of the Hungarian middle-aged, midle-class citizens living in rural areas with the sevices of the Szentes SPA. This can assist the spa's management in preparing decisions.
\end{abstract}

\section{Bevezetés}

Az utóbbi időben tapasztalható a fogyasztók részéről a rekreációs célú fürdőturizmus térnyerése, mely az egészségtudatos életmóddal van összefüggésben [2][12]. Világszerte a fürdőturizmus elsődleges lebonyolítói a fürdővárosok [7][8], melyek között egyre nagyobb verseny folyik a fogyasztókért [4][11]. Nincs ez másként Magyarországon sem, mivel a magyar gazdaság egyik legjelentősebb szektora a turizmus, melyen belül egyre inkább meghatározó a fürdőturizmus [10][5]. Közismert, hogy a hazai fürdővagyon a Dél-alföldi régióban koncentrálódik [6], ahol olyan jelentős fürdővárosok találhatók mint például Gyula, Makó, Mórahalom, Szentes [1] [13]. A Szentesi Fürdő a fejlesztéseknek köszönhetően napjainkra három fürdőrészleggel (Élmény- és Wellness részleg, Termál részleg, Strandfürdő részleg) rendelkezik, melynek célcsoportjai a gyógyulni és rekreálódni vágyó háromgenerációs családok. Az elmúlt években a fürdője által országos hírnévre szert tevő Szentes a fürdőturisztikai szolgáltatások piacának növekvő fontosságú szereplője lehet, de ehhez elengedhetetlenül szükséges a fürdőlátogatók fürdőszolgáltatásokkal kapcsolatos véleményének a megismerése [15].

Kapcsolattartó szerző E-mail cím: Szabo.Zoltan.dr@szie.hu 
A kutatás célja a tág értelemben vett vidéken élö magyar középkorú középosztály elégedettségének a feltárása és megismerése a Szentesi Fürdő szolgáltatásaival kapcsolatosan, mely segítséget nyújthat a fürdő menedzsmentje számára a döntéselőkészítésben. A Szentesi Fürdőben eddig átfogó, tudományos módszerrel és alapossággal elvégzett vendégelégedettségi vizsgálat még nem készült, ezért a jelen tanulmány hiánypótlónak és további tudományos kutatások alapjának tekinthető.

\section{Módszer}

A kvantitatív kutatási módszerek közül a kérdőíves felmérést (survey) választottam a kutatási cél elérése érdekében, mely a legelterjedtebb módszer a fogyasztói vélemények felmérésére. A kérdőív elkészítésekor fontos szempontnak tartottam, hogy a feltett kérdések megválaszolása viszonylag egyszerű legyen, ezáltal jelentős mértékben csökkenteni tudjam a kitöltési időt és lerövidítsem a válaszok feldolgozási idejét.

A vizsgálathoz a ServQual modellböl indultam ki, melyböl csak a vendégek által észlelt szolgáltatás-jellemzőket kívántam vizsgálni. A ServQual modell alapján a Szentesi Fürdő fürdőszolgáltatásaihoz kapcsolódó 22 állítást tartalmazó kérdőívet szerkesztettem a szolgáltatásminőség mérésére. Az állítások öt faktorba sorolhatók, melyek a "kézzelfoghatóság" (Tangibles), a "megbízhatóság" (Reliability), a "fogékonyság" (Responsiveness) a fürdővendég igényeire, a "szavatolás, bizalom" (Assurance) és az "empátia" (Emphaty). A kézzelfoghatóság faktorban lévő állításcsoport a megjelenéssel és a kényelemmel foglalkozik, vagyis ezzel az állításcsoporttal a Szentesi Fürdő épületeivel, berendezési tárgyaival, kommunikációs eszközeivel és személyzetével való vendég-elégedettséget mértem. A megbízhatóság faktorban lévő állításcsoport az ígérettel és a hibamentességgel foglalkozik, vagyis a válaszadó azzal való elégedettségét mértem, hogy a fürdő képes-e az ígért fürdőszolgáltatást megbízhatóan és pontosan biztosítani. A fogékonyság faktorban lévő kérdéscsoporttal azt vizsgáltam, hogy a fürdő a vendég számára hajlandó-e segíteni és azt azonnal megteszi-e. A szavatolás, bizalom faktorban lévő kérdéscsoporttal a fürdőlátogató elégedettségére voltam kíváncsi a fürdő munkatársainak tudása, ismerete, udvariassága, valamint képességükre a bizalom, illetve a megbízhatóság sugározása vonatkozásában. Végül az empátia faktorban lévő kérdéscsoporttal azt mértem fel, hogy a válaszadók mennyire elégedettek azzal, amennyire a fürdő személyzete személyre szabottan gondoskodik róluk [9].

A kérdőívben a ServQual modell alapján Likert-féle intervallum skálán mérhető kérdésfeltevést valósítottam meg. Az egyetértés mértékének méréséhez az ötfokozatú skálát választottam, mert a válaszadók ezt tudják a legjobban értelmezni, mint az iskolában az 1-töl 5-ig osztályzatokat, az "egyáltalán nem ért egyet"-től a "teljesen egyetért"-ig. A kérdőívben szereplő további hét kérdéssel fel kívántam tárni a megkérdezettek szocio-demográfiai jellemzőit. Ennek érdekében rákérdeztem a válaszadó nemére, korára, gazdasági aktivitására, legmagasabb iskolai végzettségére, lakhelyére, családi állapotára, gyógyvízzel kezelhető egészségügyi problémájára és családjának jövedelemszintjére [3]. Az adatgyűjtés eszközeként hagyományos papír alapú kérdőívet használtam, melyet közvetítőn keresztül juttattam el a válaszadókhoz. A válaszadók randomizált módszerrel lettek kiválasztva a Szentesi Fürdőben. A válaszadókkal szemben támasztott követelmény az volt, hogy nagykorú és magyar állampolgárságú turista legyen.

Az adatgyüjtésre 2017. november 6. napja és 2018. január 15. napja közötti időszakban került sor. Az adatgyüjtés során a szükséges számú minta elérése érdekében 150 darab kérdőív került kitöltésre, melyből 125 darab volt értékelhető, mely a minta lett. A kvantitatív kutatás megtervezése és végrehajtása során figyelembe vettem a statisztikáról szóló 1993. évi XLVI. törvényt, különös tekintettel annak a statisztikai adatgyüjtések (8-9.), a hivatalos statisztikai szolgálathoz nem tartozó szervek statisztikai adatgyüjtése (15-16.), és a statisztikai adatok nyilvánossága, védelme, továbbítása (17-21.) paragrafusait. A kérdőíves válaszok számítógépes rögzítését követően, a kutatási célom elérése érdekében a begyüjtött adatok jellegzetességeit figyelembe véve a leíró statisztikai elemzést választottam. A statisztikai elemzéshez a Statistical Package for the Social Sciences (SPSS 23.0) Windows 10 programcsomagot használtam. Az SPSS programcsomagot azért alkalmaztam, mert ennek a programcsomagnak a segítségével a statisztikai elemzéseket pontosan és hatékonyan tudtam elvégezni [14]. 


\section{Eredmények}

A kapott adatokból elöször meghatároztam a válaszadók szocio-demográfiai jellemzőit, majd a fürdőszolgáltatásokkal való elégedettségüket vizsgáltam meg. A vizsgálatom további részében azokra a fürdőszolgáltatásokra koncentráltam, melyekkel kapcsolatban a legnagyobb és a legkisebb volt a fürdőturisták elégedettségének mértéke.

\subsection{A válaszadók szocio-demográfiai jellemzői}

A kérdőívet értékelhetően kitöltő 125 fő válaszadó átlag életkora 35,16 év volt, további szociodemográfiai jellemző tulajdonságaik a következők (1. táblázat).

1. táblázat. $A$ válaszadók szocio-demográfiai jellemzői $(N=125)$

\begin{tabular}{|c|c|c|c|}
\hline \multicolumn{2}{|l|}{ Jellemzők } & fő & $\%$ \\
\hline \multirow{2}{*}{ Nem } & Nö & 71 & $56,80 \%$ \\
\hline & Férfi & 54 & $43,28 \%$ \\
\hline \multirow{4}{*}{$\begin{array}{l}\text { Lakóhely településtípus } \\
\text { szerint }\end{array}$} & Budapest & 20 & $16,08 \%$ \\
\hline & Megyeszékhelyi város & 38 & $30,48 \%$ \\
\hline & Egyéb város & 49 & $39,28 \%$ \\
\hline & Község & 18 & $14,48 \%$ \\
\hline \multirow{3}{*}{ Gazdasági aktívitás } & Inaktív & 13 & $10,48 \%$ \\
\hline & Fizikai dolgozó & 56 & $44,88 \%$ \\
\hline & Szellemi dolgozó & 56 & $44,88 \%$ \\
\hline \multirow{2}{*}{ Családi állapot } & Egyedül él & 51 & $40,88 \%$ \\
\hline & Kapcsolatban él & 74 & $59,28 \%$ \\
\hline \multirow{2}{*}{$\begin{array}{l}\text { Gyógyvízzel kezelhető } \\
\text { egészségügyi probléma }\end{array}$} & Van & 36 & $28,88 \%$ \\
\hline & Nincs & 89 & $71,28 \%$ \\
\hline \multirow{4}{*}{ Jövedelemérzet } & Csak a legszükségesebbre elég a jövedelmük & 7 & $5,68 \%$ \\
\hline & Szerényen, de megélnek & 28 & $22,48 \%$ \\
\hline & Jövedelemszintük átlagos & 65 & $52,08 \%$ \\
\hline & Jövedelemszintjük átlag feletti & 25 & $20,08 \%$ \\
\hline \multirow{4}{*}{$\begin{array}{l}\text { Legmagasabb iskolai } \\
\text { végzettség }\end{array}$} & Általános iskola & 15 & $12,08 \%$ \\
\hline & Szakmunkásképző & 21 & $16,88 \%$ \\
\hline & Érettségi & 53 & $42,48 \%$ \\
\hline & Egyetem, főiskola & 36 & $28,88 \%$ \\
\hline
\end{tabular}

Forrás: Saját szerkesztés

A megkérdezettek nemek szerinti összetételében a nök aránya $(56,80 \%)$ nagyobb volt, mint a férfiaké $(43,28)$. A válaszadók kisebb része községben $(14,48 \%)$ nagyobbik része $(85,84 \%)$ városban él. A megkérdezettek közül a városban lakók körében legtöbben az egyéb városban, legkevesebben a fövárosban laknak. A megkérdezettek - gazdasági aktivitásukat - tekintve döntö többsége (89,52\%) aktív, kisebb részben (10,48\%) gazdaságilag inaktív. A gazdaságilag aktívak közül ugyan akkora arányt képviselnek a szellemi foglalkozásúak (44,88\%), mint a fizikai foglalkozásúak (44,88\%). A válaszadók családi állapotukat tekintve nagyobb részük $(59,28 \%)$ 
párkapcsolatban, kisebb részük $(40,88 \%)$ egyedül él. A megkérdezettek több mint kétharmad részének $(71,28 \%)$ nincs gyógyvízzel gyógyítható betegsége, kisebb részének $(28,88 \%)$ van. A megkérdezettek jövedelemszintjét tekintve döntö többségben vannak azok, akik jövedelemszintjüket átlagosnak ítélik meg (1. ábra).

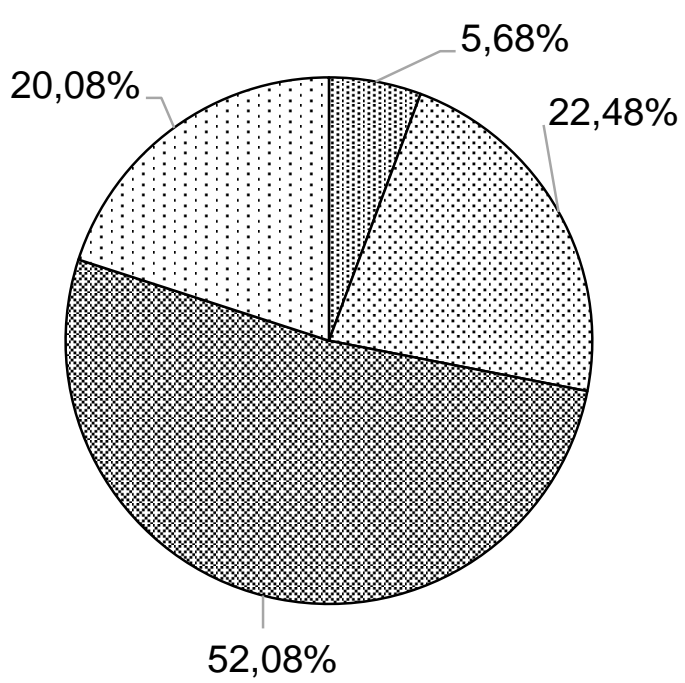

国 Csak a legszükségesebbre elég a jövedelmük

Szerényen, de megélnek

図Jövedelemszintük átlagos

$\square$ Jövedelemszintjük átlag feletti

1. ábra. A válaszadók családi jövedelemszintje Forrás: Saját szerkesztés

A válaszadók a családi jövedelemszintjüket nagyrészt (52,08\%) átlagosnak és szerénynek $(22,48 \%)$ tekintik. Legkevesebben azok vannak, akik jövedelemszintje átlag feletti $(20,08 \%)$ és azok, akiknek a jövedelme csak a legszükségesebbre elég (5,68\%). A megkérdezettek iskolai végzettségét tekintve döntő többségük érettségit adó középiskolai, vagy annál magasabb iskolai végzettséggel rendelkezik (2. ábra).

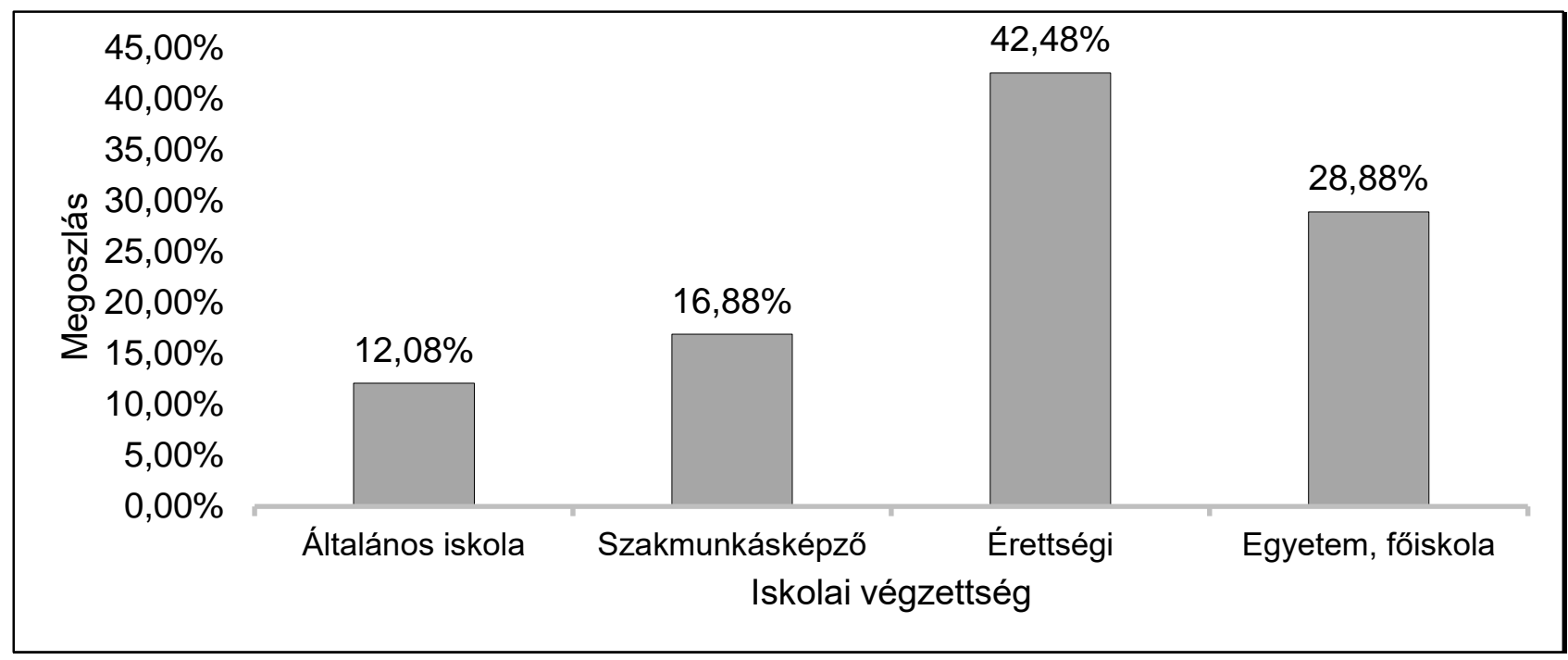

2. ábra: A válaszadók iskolai végzettsége

Forrás: Saját szerkesztés

A megkérdezettek 42,48\%-nak a legmagasabb iskolai végzettsége érettségit adó középiskola, őket követik csökkenő sorrendben a felsőfokú végzettségüek (egyetem, főiskola) 28,88\%-kal, a szakmunkásképző intézetben végzettek $16,88 \%$-kal, majd az általános iskolai végzettségüek $12,08 \%$-kal. 


\subsection{A fürdőszolgáltatásokkal való elégedettség}

A fürdőturisták a fürdőszolgáltatásokkal jelentős mértékben elégedettek, mert a válaszadók a fürdőszolgáltatásokkal való átlagos elégedettségük átlaga 4,16 (2. táblázat).

2. táblázat. Fürdőszolgáltatásokkal való elégedettség $(N=125)$

\begin{tabular}{|c|c|c|c|c|c|c|}
\hline s. & Állítás & $\min$ & $\max$ & terj. & átlag & szórás \\
\hline 1. & A fürdő modern felszereltséggel rendelkezik. & 2 & 5 & 3 & 3,93 & 0,977 \\
\hline 2. & $\begin{array}{l}\text { A fürdő fizikai megjelenése, arculata, létesítményei vizuálisan } \\
\text { vonzók. }\end{array}$ & 1 & 5 & 4 & 4,02 & 0,907 \\
\hline 3. & A fürdő munkatársai jól öltözöttek, elegáns megjelenésűek. & 2 & 5 & 3 & 4,06 & 0,944 \\
\hline 4. & $\begin{array}{l}\text { A fürdőszolgáltatáshoz kapcsolódó, információforrások (honlap, } \\
\text { tájékoztatók, árlisták, nyomtatványok) vizuálisan vonzók. }\end{array}$ & 2 & 5 & 3 & 3,88 & 0,876 \\
\hline 5. & $\begin{array}{l}\text { Amikor a fürdő munkatársai valamit (pl. egy feladat elvégzését) } \\
\text { meghatározott időre ígérnek, azt be is tartják. }\end{array}$ & 1 & 5 & 4 & 4,08 & 0,894 \\
\hline 6. & $\begin{array}{l}\text { Amennyiben Önnek problémája adódik, a fürdő munkatársai } \\
\text { öszinte szándékot mutat annak megoldására. }\end{array}$ & 1 & 5 & 4 & 4,27 & 0,910 \\
\hline 7. & $\begin{array}{l}\text { A fürdő megfelelő szolgáltatást nyújt már az első alkalommal } \\
\text { úgy, hogy Önnek érdemes újra visszatérnie. }\end{array}$ & 2 & 5 & 3 & 4,17 & 0,801 \\
\hline 8. & A fürdő a szolgáltatásait az előre meghirdetett időben biztosítja. & 2 & 5 & 3 & 4,14 & 0,855 \\
\hline 9. & A fürdő ragaszkodik a hibamentes tevékenységhez. & 1 & 5 & 4 & 4,00 & 0,925 \\
\hline 10. & $\begin{array}{l}\text { A fürdő munkatársai pontosan tájékoztatják Önt a } \\
\text { szolgáltatások nyújtásának időpontjáról, időtartamáról. }\end{array}$ & 2 & 5 & 3 & 4,26 & 0,795 \\
\hline 11. & $\begin{array}{l}\text { A fürdő munkatársai kérésre azonnali segítséget nyújtanak } \\
\text { Önnek. }\end{array}$ & 2 & 5 & 3 & 4,28 & 0,789 \\
\hline 12. & A fürdő munkatársai mindig készek Önnek segítséget nyújtani. & 2 & 5 & 3 & 4,34 & 0,782 \\
\hline 13. & $\begin{array}{l}\text { A fürdő munkatársai soha nem túl elfoglaltak ahhoz, hogy az } \\
\text { Ön kérdéseire válaszoljanak. }\end{array}$ & 2 & 5 & 3 & 4,18 & 0,827 \\
\hline 14. & A fürdő munkatársainak viselkedése bizalmat ébreszt Önben. & 1 & 5 & 4 & 4,17 & 0,840 \\
\hline 15. & $\begin{array}{l}\text { Ön, mint fürdővendég, biztonságban érzi magát a fürdö } \\
\text { területén. }\end{array}$ & 2 & 5 & 3 & 4,23 & 0,834 \\
\hline 16. & $\begin{array}{l}\text { A fürdő munkatársai folyamatosan előzékenyek és udvariasak } \\
\text { Önnel. }\end{array}$ & 3 & 5 & 2 & 4,39 & 0,671 \\
\hline 17. & $\begin{array}{l}\text { A fürdő munkatársai birtokában vannak annak a tudásnak, } \\
\text { amellyel az Ön kérdéseire megfelelő válaszokat adhatnak. }\end{array}$ & 2 & 5 & 3 & 4,21 & 0,786 \\
\hline 18. & $\begin{array}{l}\text { A fürdő munkatársai megkülönböztetett figyelmet szentelnek } \\
\text { Önnek. }\end{array}$ & 1 & 5 & 4 & 4,21 & 0,816 \\
\hline 19. & A fürdő nyitvatartási ideje megfelel Önnek. & 1 & 5 & 4 & 4,18 & 0,846 \\
\hline 20. & $\begin{array}{l}\text { A fürdő rendelkezik olyan munkatársakkal, akik az Önnel } \\
\text { egyedileg, személyesen foglalkoznak. }\end{array}$ & 1 & 5 & 4 & 4,26 & 0,851 \\
\hline 21. & A fürdő az Ön érdekeit állítja a középpontba. & 1 & 5 & 4 & 4,17 & 0,849 \\
\hline 22. & A fürdő munkatársai felismerik az Ön különleges igényeit. & 1 & 5 & 4 & 4,18 & 0,919 \\
\hline
\end{tabular}

Forrás: Saját szerkesztés

A legmagasabb átlagértéket $(4,39)$ „A fürdő munkatársai folyamatosan előzékenyek és udvariasak Önnel” állítás, a legalacsonyabb átlagértéket $(3,88)$ pedig „A fürdőszolgáltatáshoz kapcsolódó, információforrások vizuálisan vonzók" állítás kapta. 
A fürdőszolgáltatásokkal kapcsolatos 22 állítás öt elégedettségi faktorát értéksorrendbe állítva megállapítható, hogy a válaszadók az egyes faktorokat egymástól karakterisztikusan elkülönítik, de közöttük nem érzékelnek jelentős különbségeket (3. ábra).

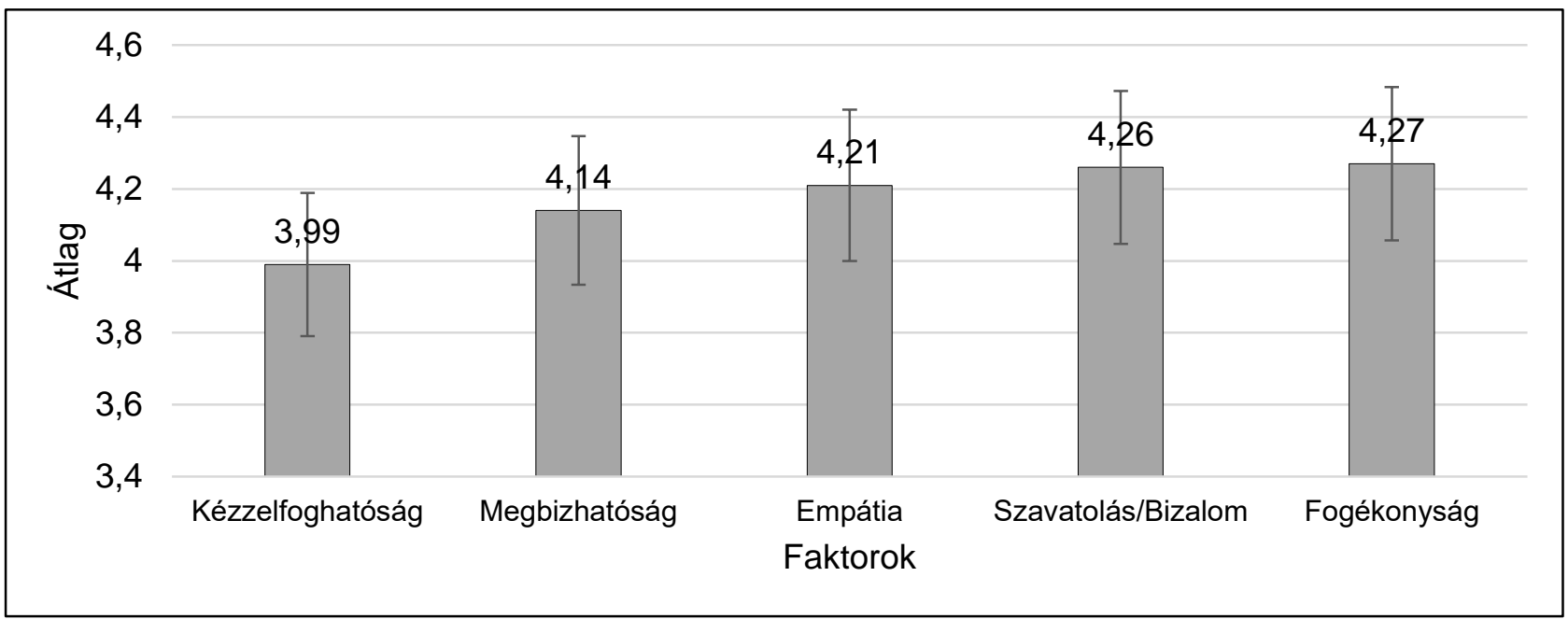

3. ábra. Elégedettségi dimenziók átlagai

Forrás: Saját szerkesztés

A fürdővendégek legnagyobb elégedettséget a „fogékonyság” (4,27) és a „szavatolás/bizalom” $(4,26)$ faktorokban jelöltek meg. Jelentős volt még a megkérdezettek elégedettsége az „empátia” faktorban is $(4,21)$. A válaszadók legkisebb elégedettséget a „megbízhatóság” $(4,14)$ és a „kézzelfoghatóság” $(3,99)$ faktorokkal kapcsolatban mutattak.

\subsection{A fürdőszolgáltatásokkal kapcsolatos legnagyobb elégedettség}

A fürdőszolgáltatásokkal kapcsolatos 22 állítás a válaszadók elégedettségi átlagértékei alapján csökkenő sorrendbe lettek rendezve. Az elégedettségi sorrend első részében az átlagértékek kivétel nélkül a 4-es értéknél magasabbak (3. táblázat).

3. táblázat. A fürdőszolgáltatásokkal kapcsolatos legnagyobb elégedettség $(N=125)$

\begin{tabular}{|c|c|c|c|c|c|}
\hline Állítás & $\min$ & $\max$ & terj. & átlag & szórás \\
\hline $\begin{array}{l}\text { A fürdő munkatársai folyamatosan előzékenyek és udvariasak } \\
\text { Önnel. }\end{array}$ & 3 & 5 & 2 & 4,39 & 0,671 \\
\hline A fürdő munkatársai mindig készek Önnek segítséget nyújtani. & 2 & 5 & 3 & 4,34 & 0,782 \\
\hline $\begin{array}{l}\text { A fürdő munkatársai kérésre azonnali segítséget nyújtanak } \\
\text { Önnek. }\end{array}$ & 2 & 5 & 3 & 4,28 & 0,789 \\
\hline $\begin{array}{l}\text { Amennyiben Önnek problé } \\
\text { öszinte szándékot mutat ar }\end{array}$ & 1 & 5 & 4 & 4,27 & 0,910 \\
\hline $\begin{array}{l}\text { A fürdő munkatársai pontosan tájékoztatják Önt a szolgáltatások } \\
\text { nyújtásának időpontjáról, időtartamáról. }\end{array}$ & 2 & 5 & 3 & 4,26 & 0,795 \\
\hline $\begin{array}{l}\text { A fürdő rendelkezik olyan munkatársakkal, akik az Önnel } \\
\text { egyedileg, személyesen foglalkoznak. }\end{array}$ & 1 & 5 & 4 & 4,26 & 0,851 \\
\hline Ön, mint fürdővendég, biztonságban érzi magát a fürdő területén. & 2 & 5 & 3 & 4,23 & 0,834 \\
\hline
\end{tabular}

Forrás: Saját szerkesztés 
A fürdőszolgáltatásokkal kapcsolatos legnagyobb elégedettséget jelentő első egyharmadban az öt elégedettségi faktor közül négy megtalálható és csak a „kézzelfoghatóság” faktor nem került be. A fürdőturisták a fürdőszolgáltatásokkal kapcsolatos hét állítás közül a legnagyobb elégedettséget a „fogékonyság” és a „szavatolás, bizalom” míg a legkisebb elégedettséget a „megbízhatóság” és az „empátia” faktorokban mutattak.

A legnagyobb elégedettséget jelentő „fogékonyság” faktorhoz tartozó válaszadói állítások alapján megállapítható, hogy a fürdő munkatársai hajlandók segíteni és azt azonnal meg is teszik a fürdővendégek számára. A másik nagy elégedettséget jelentő „szavatolás, bizalom” faktorhoz tartozó állítások alapján megállapítható, hogy a fürdőturisták elégedettek a fürdő munkatársainak udvariasságával és a fürdő munkatársai képesek megbízhatóságot sugározni a fürdővendégek számára.

Megállapítható továbbá az „empátia” faktorhoz tartozó állítás alapján, hogy a válaszadók, ha nem is teljes körüen, de elégedettek azzal, amennyire a fürdő személyre szabottan gondoskodik róluk.

\subsection{A fürdőszolgáltatásokkal kapcsolatos legkisebb elégedettség}

Az elégedettségi sorrend utolsó részében, melyekkel a legkisebb volt a válaszadók elégedettsége, viszonylagosan magas átlagértékek jelentek meg, de viszonylag alacsony egyetértés mellett (4. táblázat).

4. táblázat. A fürdőszolgáltatásokkal kapcsolatos legkisebb elégedettség ( $N=125)$

\begin{tabular}{|l|c|c|c|c|c|}
\hline Állítás & $\min$ & $\max$ & terj. & átlag & szórás \\
\hline A fürdő a szolgáltatásait az előre meghirdetett időben biztosítja. & 2 & 5 & 3 & 4,14 & 0,86 \\
\hline $\begin{array}{l}\text { Amikor a fürdő munkatársai valamit (pl. egy feladat elvégzését) } \\
\text { meghatározott időre ígérnek, azt be is tartják. }\end{array}$ & 1 & 5 & 4 & 4,08 & 0,89 \\
\hline A fürdő munkatársai jól öltözöttek, elegáns megjelenésűek. & 2 & 5 & 3 & 4,06 & 0,94 \\
\hline $\begin{array}{l}\text { A fürdő fizikai megjelenése, arculata, létesítményei vizuálisan } \\
\text { vonzók. }\end{array}$ & 1 & 5 & 4 & 4,02 & 0,91 \\
\hline A fürdő ragaszkodik a hibamentes tevékenységhez. & 1 & 5 & 4 & 4,00 & 0,93 \\
\hline A fürdő modern felszereltséggel rendelkezik. & 2 & 5 & 3 & 3,93 & 0,98 \\
\hline $\begin{array}{l}\text { A fürdőszolgáltatáshoz kapcsolódó, információforrások (honlap, } \\
\text { tájékoztatók, árlisták, nyomtatványok) vizuálisan vonzók. }\end{array}$ & 2 & 5 & 3 & 3,88 & 0,88 \\
\hline
\end{tabular}

Forrás: saját szerkesztés

A fürdőszolgáltatásokkal kapcsolatos legkisebb elégedettséget jelentő utolsó egyharmadban az öt elégedettségi faktor közül kettő található meg, úgymint a „kézzelfoghatóság” és a „megbízhatóság” faktorok. A legkisebb elégedettséget jelentő hét állítás közül legtöbb, vagyis négy állítás a „kézzelfoghatóság”, három állítás a „megbízhatóság” faktorba tartozik.

A kismértékű elégedettséget jelentő „megbízhatóság” faktor állításai alapján megállapítható, hogy a fürdő kevésbé képes az ígért fürdőszolgáltatást megbízhatóan és az ígért pontossággal biztosítani a fürdővendégek számára.

A legkisebb mértékü elégedettséget jelentő „kézzelfoghatóság” faktor állításainak midegyike szerepel a fürdőszolgáltatásokkal kapcsolatos legkisebb elégedettséget jelentő utolsó egyharmadban. Ez alapján megállapítható, hogy a fürdővendégek legkevésbé elégedettek a fürdő épületeinek, berendezési tárgyainak kényelmével, valamint a kommunikációs eszközökkel és a személyzet megjelenésével. 


\section{Következtetések}

A mintában sikerült elérni a célkitüzés szerinti vidéki városban élö, középfokú végzettségü, átlagos jövedelemmel rendelkező, magyar fürdővendégeket.

A válaszadók fürdőszolgáltatásokkal való elégedettségének magas átlagából az következik, hogy a Szentesi Fürdő szolgáltatásaival nagymértékben elégedettek a fürdőturisták. A fürdővendégek legnagyobb elégedettséget a „fogékonyság” és a „szavatolás/bizalom” faktorokban mutattak, melyböl az következik, hogy a fürdőturisták számára a Szentesi Fürdő alkalmazottai hajlandók segíteni és azt azonnal meg is teszik, valamint a fürdő munkatársai udvariasak és képesek megbízhatóságot sugározni. A fürdővendégek legkisebb elégedettséget a „megbízhatóság” és a „kézzelfoghatóság” faktorokban mutattak, melyböl az következik, hogy a fürdő kevésbé képes az ígért fürdőszolgáltatást megbízhatóan és az ígért pontossággal biztosítani, valamint a fürdővendégek legkevésbé elégedettek a fürdő épületeivel, berendezési tárgyaival, valamint a kommunikációs eszközökkel és a személyzet megjelenésével.

A kutatás megállapításai és a levont következtetések alapján javasolt a Szentesi Fürdö menedzsmentjének, hogy a személyzet számára, - különös tekintettel a vendégtérben dolgozókra célszerü lenne egységes formaruhát biztosítani és nagyobb gondot fordítani a dolgozók megjelenésére. Továbbá javasolt, hogy a fürdő épületét, berendezéseit, eszközeit folyamatosan korszerüsítsék és fordítsanak nagyobb hangsúlyt a kommunikációs eszközök, különös tekintettel a digitális alapú, elsősorban az internetes, valamint a közösségi media megjelenésének fejlesztésére.

A kutatás elérte célját, mert a vizsgálat során feltárásra került a tág értelemben vett magyar középkorú középosztály elégedettsége a Szentesi Fürdő szolgáltatásaival kapcsolatosan. A kapott eredményekből levont következtetések és javaslatok alkalmasak a fürdő menedzsmentje számára a döntéselőkészítés segítésére.

Anyagi támogatás: A közlemény megírása, illetve a kapcsolódó kutatómunka anyagi támogatásban nem részesült.

Érdekeltségek: A szerzőnek nincsen érdekeltsége.

\section{Irodalomjegyzék}

[1] Albel, A., Tokaji, F. (2006): Alföld Spa Gyógyítás és wellness a Dél-Alföld termálfürdőiben. Schneider Nyomda Kft. Gyula

[2] Andó, R., Fritz, P., Patakiné B. J. (2019): Életmód-szabadidő-rekreáció. In: Fritz, P. (szerk.) Alapfogalmak és jelentéseik a rekreáció területén: Rekreáció mindenkinek III. Miskolc, Miskolci Egyetemi Kiadó, pp. 10-29.

[3] Babbie, E. (2017): A társadalomtudományi kutatás gyakorlata. Balassi Kiadó, Budapest, 744 p.

[4] Chambers, T. A. (2016): Mineral springs resorts in global perspectives: spa histories, Journal of Tourism History, 8:3, pp. 321-323, DOI: 10.1080/1755182X.2017.1292657

[5] Csapó, J., Marton, G. (2017): The role and importance of spa and wellness tourism in Hungary's tourism industry. Czech Journal of Tourism, 6(1), pp. 55-68.

[6] Hojcska, Á. E. (2019a): A fürdőgyógyászati intézményrendszer egyenlőtlenségei Magyarországon. In: Kőszegi, I. R. (szerk.) III. Gazdálkodás és Menedzsment Tudományos Konferencia: Versenyképesség és innováció. Kecskemét, Neumann János Egyetem Kertészeti és Vidékfejlesztési Kar, pp. 858-864.

[7] Hojcska, Á. E. (2019b): Experiences of a professional study visit to spa towns in Germany. In: Hojcska, Á. E. (szerk.) Changing Spa Towns: 2nd Science Papers of the Spa Towns. Túrkeve, pp. 208-227.

[8] Hojcska, Á. E., Szabó, Z. (2016): Természetes gyógytényezők és fürdővárosi gyógyintézmények Magyarországon. In: Szabó, Z. (szerk.) Fürdővárosok környezete. Túrkeve, pp. 48-74.

[9] Kenesei, Zs. (2017): A vevői elégedettség mérésének lehetőségei többdimenziós szemléletben. Statisztikai Szemle, 95 (1). pp. 29-50. DOI: 10.20311/stat2017.01.hu0029

[10] Lövei-Kalmár, K., Jeles, T., Ráthonyi, G. (2019): Analysis of Bathing Habits among Spa Visitors. Applied Studies in Agribusiness and Commerce, 13(1-2), pp. 81-90.

[11] Palkovits, I. (2016): Fürdővárosok nemzetközi versenyhelyzetben. Nyugat-magyarországi Egyetem Savaria Egyetemi Központ Tudományos Közleményei, 16, pp. 91-102.

[12] Printz-Markó, E. (2019): 'Changing bath towns' - in the spirit of sustainability: opportunities for service development along the water-based health tourism model based on the four ancient elements. In: Hojcska, Á. E. (szerk.) Changing Spa Towns: 2nd Science Papers of the Spa Towns. Túrkeve, pp. 87-111.

[13] Strack, F. (2019): Certified spas - Spa towns and the others. In: Hojcska, Á. E. (szerk.) Changing Spa Town: 2nd Science Papers of the Spa Towns. Túrkeve, pp. 47-70.

[14] Takács, Sz. (2016): Bevezetés a matematikai statisztikába, elmélet és gyakorlat. Antarész Kiadó, Budapest, 355 p.

[15] Zsarnóczky, M. (2017): Turizmustervezés az egészségturizmusban. Acta Carolus Robertus, 7, pp. 235-254. 